\title{
Trophic State and Hypolimnetic Nitrogen Metabolism of Lake Hibara*
}

\author{
Yasuhiro SATOH, Naoki KoIDE, Shigeru OASA, \\ Izumi Suzuki and Toshitaka Suzuki
}

\begin{abstract}
This is the first attempt to elucidate the seasonal changes in some physical and chemical parameters in a water column of Lake Hibara. The observation extended from spring to early winter of 1991 .

In the hypolimnion, nitrification started between 13 June and 10 July. The nitrification rate in this period was $0.21-0.44 \mu \mathrm{g}$ atom $\mathrm{N} \cdot 1^{-1} \cdot$ day $^{-1}$. The dissolved oxygen (DO) level of about $0.6-0.7 \mathrm{mg} \cdot \mathrm{l}^{-1}$ appeared critical in impeding efficient nitrification. The gross ammonia production rate was estimated to be $0.05-0.15 \mu \mathrm{g}$ atom $\mathrm{N} \cdot \mathrm{I}^{-1} \cdot \mathrm{day}^{-1}$. Denitrification seems to have taken place in the lower hypolim. nion and/or on the surface of the bottom sediment when DO decreased to $2-3 \%(0$. $\left.2-0.3 \mathrm{mg} \cdot \mathrm{1}^{-1}\right)$. The levels of TN, TP, Chl. a and transparency in the autumn circulation period indicate that the lake is on the boundary between oligo- and mesotrophic, though the epilimnetic water in summer was oligotrophic. The relative areal oxygen deficit in the hypolimnion $\left(0.055-0.061 \mathrm{mg} \cdot \mathrm{cm}^{-2} \cdot \mathrm{day}^{-1}\right)$ was at the lower limit of eutrophy. The question of why, in spite of the lake's overlying oligotrophic epilimnion, the hypolimnetic DO consumption rate was at a eutrophic level remained to be solved. The hypolimnetic DO consumption rate seems to have been accelerating for the last 20 years. To elucidate the extent of the fluctuation of the hypolimnetic processes from year to year is important for future study.
\end{abstract}

Key words: Lake Hibara, trophic state, oxygen consumption, nitrogen metabolism.

\section{Introduction}

Lake Hibara $\left(37^{\circ} 41^{\prime} \mathrm{N}, 140^{\circ} 03^{\prime} \mathrm{E}\right)$ in Fukushima, Japan is one of those lakes whose history is clearly known. It began with the eruption of the volcanic Mt. Bandai on 15 July, 1888. The summit of the volcano, $1.7 \mathrm{~km}^{3}$ in volume, was blown away by the eruption (Murayama, 1973). Large scale mudflows caused by the eruption had dammed the valleys of many rivers including the Hibara and Osuzawa Rivers. In consequence, a large number of lake basins, including Lake Hibara and Lake Osuzawa, were formed. These two basins remained independent of each other for a while. However, as water filled the basins, water levels rose and the surface areas enlarged. Finally, both lakes were joined in 1900 (TANAKA, 1903). The lake so formed took the name of the larger basin, Hibara.

HoRIE (1961) described the morphology of Lake Hibara. The altitude is $819 \mathrm{~m}$ above mean sea level. Its maximum depth is $31 \mathrm{~m}$ with a mean depth of $12 \mathrm{~m}$. However, the water level is not constant since lake water is used for hydropower generation. The lake covers $10.83 \mathrm{~km}^{2}$ and contains $0.13 \mathrm{~km}^{3}$ of water. Its maximum length and maximum

* Contribution No 17, from Urabandai Limnological Station, Yamagata University. 
breadth are $10.5 \mathrm{~km}$ and $2.8 \mathrm{~km}$, respectively. The length of shoreline is $37.5 \mathrm{~km}$ and shoreline development is 3.22 .

Limnological study of this lake is limited. The earliest study was a measurement of water temperature by TANAKA (1903). Two vertical profiles of water temperature in July, 1901 and 1902 are available in his study. Yoshumura (1935a, b, c) carried out the first comprehensive limnological studies on the Bandai volcanic lakes, including Lake Hibara. His studies covered morphology, water temperature, water chemistry and organisms, though he sampled only in July and August. Subsequent studies focused principally on plankton (KoKUBO and Kawamura, 1941; Watanabe et al., 1973; Kurosaki and Kadota, 1989) and benthos (Kitagawa, 1974). Some depth profiles for physical and chemical parameters are available in their studies. However, these authors collected samples only once or twice, mainly in summer. Essentially, extensive seasonal data on any limnological aspect of this lake have not been available.

We measured some physical and chemical parameters of the water of Lake Hibara from April to December, 1991. These are the first results reported on a seasonal basis from spring to early winter.

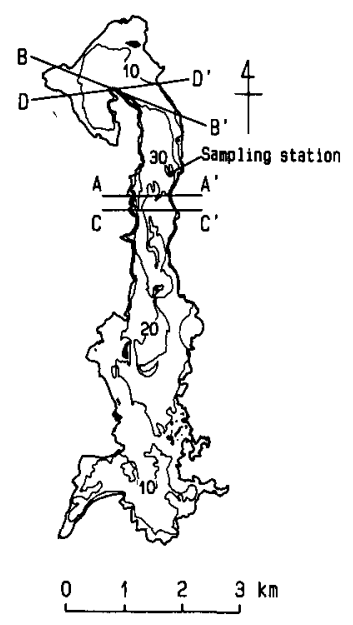

Fig. 1. Map showing station location. See text for straight lines.

\section{Materials and methods}

Water samples were collected from a station shown in Figure 1 with a 3 liter Van Dorn bottle once a month from April to December, 1991. Water samples from $5 \mathrm{~m}$ depth intervals were kept in 1 liter clean polyethylene bottles which were stored in a heat insulating box and transported to a laboratory at Yamagata University. Filtration of the water samples through Whatman GF/F glass fiber filters

Table 1. Measured parameters and methods used.

\begin{tabular}{ll}
\hline \multicolumn{1}{c}{ Parameters } & \multicolumn{1}{c}{ Methods } \\
Water temperature & Thermistor thermometer (Takara Co. Ltd., SPD-1 D) \\
Transparency & Secchi disk \\
Dissolved oxygen & Winkler method \\
Chl. a & SCOR/UNESCO (1966) \\
Total nitrogen & UV measurement after persulfate digestion (OTSUKI, \\
& 1981) \\
Total phosphorus & Molybdate blue method after persulfate digestion \\
& (MENTzEL and CoRwIN, 1965) \\
Ammonia & Phenol hypochlorite method (SOLORZANO, 1969) \\
Nitrate & Cadmium reduction method (STRICKLAND and PARSONS, \\
& 1972) \\
Nitrite & BENDSCHNEIDE and RoBINSON (1952) \\
Reactive phosphorus & Molybdate blue method (STRICKLAND and PARSONS, 1972) \\
\hline
\end{tabular}


(nominal porosity, $0.7 \mu \mathrm{m}$ ) was started within 4 hr after sample collection. Aliquots of the filtrates were kept in clean polyethylene bottles and stored frozen prior to chemical analysis. Measured physical and chemical parameters and the methods used are shown in Table 1.

The units of concentration used in this study are $\mu \mathrm{g}$ atom $\mathrm{N} \cdot 1^{-1}$ for nitrogenous nutrients and $\mu \mathrm{g}$ atom $\mathrm{P} \cdot \mathrm{l}^{-1}$ for phosphorus nutrients. When the former is multiplied by 14.0 , the atomic weight of nitrogen, the product is the concentration in $\mu \mathrm{g} \mathrm{N} \cdot \mathrm{l}^{-1}$ or ppb. Similarly, when the latter is multiplied by 31.0 , the atomic weight of phosphorus, the product is the concentration in $\mu \mathrm{g} \mathrm{P} \cdot 1^{-1}$ or $\mathrm{ppb}$.

\section{Results and discussion}

\section{3-1. Water temperature}

Lake Hibara is a dimictic lake. There was a $3.5^{\circ} \mathrm{C}$ difference in water temperature between surface $\left(7.1^{\circ} \mathrm{C}\right)$ and bottom $\left(3.6{ }^{\circ} \mathrm{C}\right)$ on 22 April, 1991 (Fig. 2A). However, no clear thermocline existed. About one month later, there were two thermoclines: one was from 3 to $7 \mathrm{~m}$ with a temperature difference of about $3{ }^{\circ} \mathrm{C}$, and the other was from 14 to $20 \mathrm{~m}$ with a temperature difference of about $2{ }^{\circ} \mathrm{C}$. The water temperature of the epilimnion was above $20^{\circ} \mathrm{C}$ from late June to mid-September. During this period, beside the major thermocline, a minor one still existed, though the latter does not emarge clearly in Figure 2A. The major thermocline was from 4 to $12 \mathrm{~m}$ with a temperature difference of about $10{ }^{\circ} \mathrm{C}$. The minor one was between 19 and $23 \mathrm{~m}$ with a temperature difference of about $1{ }^{\circ} \mathrm{C}$. Although partial circulation began in October, circulation was still incomplete in early November. The water temperature of the lower hypolimnion was about $1{ }^{\circ} \mathrm{C}$ lower than that of the overlying circulating water (Fig. 2A). Due to this difference in water temperature the concentration gradients of substances just above the bottom remained (e.g. Fig. 2B, 4A, 4B). Water circulated throughout the water column on 20 December. The lake is generally covered with ice from January to February or March.

\section{3-2. Dissolved oxygen}
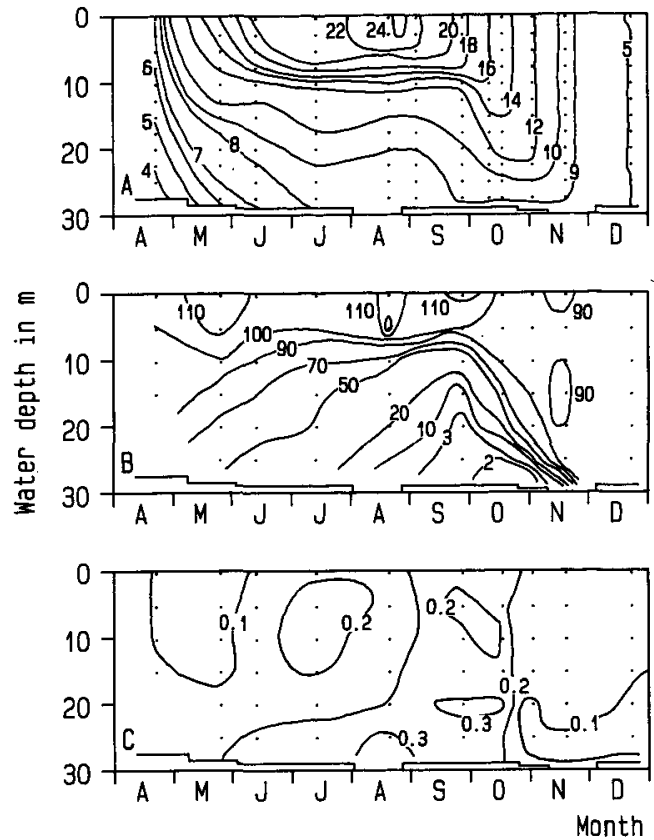

Fig. 2. Depth-time diagrams. A) water temperature $\left({ }^{\circ} \mathrm{C}\right)$; B) DO $(\%)$; C) reactive phosphorus $\left(\mu \mathrm{g}\right.$ atom $\left.\mathrm{P} \cdot 1^{-1}\right)$.

Dissolved oxygen (DO) in the epilimnion was saturated or slightly oversaturated until the end of September (Fig. 2B). It was slightly undersaturated between 90 and $100 \%$ after partial circulation began. DO below the metalimnion decreased with time during the stratification period. The low DO water mass having DO below $3 \%$ saturation stayed in the lower hypolimnion for two months from September to October. The lowest concentration was 0.17 $\mathrm{mg} \cdot 1^{-1}(1.7 \%)$ at $27.5 \mathrm{~m}$ on 31 October.

Four depth profiles of DO by previous authors, probably at the same station in this study, are available (Fig. 3A). Since their samples were collected over a rather short time period from mid-July to early August, it is possible to compare the change in the speed of hypolimnetic DO consumption in early summer. The depth profiles in 1931 (Yoshimura, 1935b), 1941 (Kokubo and Kawamura, 1941) and 1972 (WATANABE et $a l ., 1973$ ) are essentially identical (Fig. 3A), indicating that the hypolimnetic oxygen consumption rate remained unchanged for about 40 years from 1931 to 1972 . The depth profile on 5 August, 1973 (Kitagawa, 1974) dif- 
fers from the observation of Watanabe $e t$ al. (1973) conducted about a year earlier. Compared with the results in 1972, the 1973 DO levels in the epi- and metalimnion is higher, whereas that in the hypolimnion is lower. These facts indicate that the primary productivity and hypolimnetic oxygen consumption rate fluctuated from year to year at least during the 1970s.

To facilitate comparison of results between the present study and the previous studies, the depth profiles on 19 July and 5 August, 1991 were interpolated (Fig. 3B) from Figure 2B. Since the depth profiles in 1931, 1941 and 1972 are essentially the same (Fig. $3 \mathrm{~A}$ ), the depth profile on 19 July, 1941 serves as representative. On the other hand, the depth profile on 5 August, 1973 is representative of higher productivity in the photic zone and higher DO consumption in the hypolimnion in the 1970s. Not only the interpolated profile on 19 July, but also that on 5 August, 1991 shows a significant decrease in the hypolimnetic DO level compar-

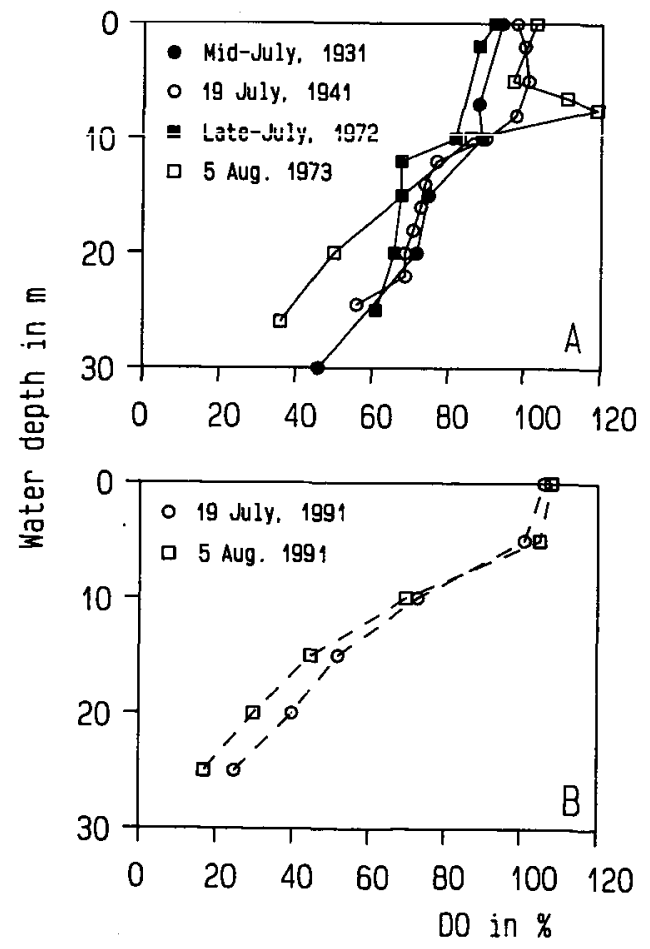

Fig. 3. Depth profiles for DO (\%). A) from previous studies; B) interpolated from Figure 2B. ed with the depth profiles on the corresponding dates in the previous studies. It is noteworthy that even when compared with the higher extreme (5 Aug. 1973), the hypolimnetic DO consumption was greater in 1991. From these results, it seems that the hypolimnetic DO consumption rate has accelerated over these 20 years. However, care must be taken in reach. ing this conclusion, since the hypolimnetic DO consumption may fluctuate as it did in the 1970s. Further seasonal study is needed to confirm whether or not this fluctuation occurs in Lake Hibara, and if it occurs, to elucidate whether the present results represent a higher, lower or intermediate DO consumption rate.

\section{3-3. Nutrients}

The concentration of nutrients in the epi- and metalimnion during the summer stratification period was low. Although reactive phosphorus was up to $0.25 \mu \mathrm{g}$ atom $\mathrm{P} \cdot \mathrm{I}^{-1}$ at $5 \mathrm{~m}$ on $10 \mathrm{July}$, in general it remained between 0.1 and $0.2 \mu \mathrm{g}$ atom $\mathrm{P} \cdot 1^{-1}$ (Fig. 2C). Ammonia was $1-2 \mu \mathrm{g}$ atom $N \cdot 1^{-1}$ (Fig. 4A). Nitrate was below $1 \mu \mathrm{g}$ atom $\mathrm{N} \cdot 1^{-1}$ in 0 to $5 \mathrm{~m}$ stratum and $1-8 \mu \mathrm{g}$ atom $\mathrm{N} \cdot 1^{-1}$ in 5 to $10 \mathrm{~m}$ stratum (Fig. 4B). Nitrite was below $0.1 \mu \mathrm{g}$ atom $\mathrm{N} \cdot \mathrm{l}^{-1}$ (Fig. 4C).

Changes in the concentration of nitrogenous nutrients in the hypolimnion passed through typical stages intermediated by nitrification and denitrification (Fig. 4A, B, C). High concentration of ammonia in May and June in the lower hypolimnion disappeared in July (Fig. 4A). At the same time, DO decreased while nitrate increased rapidly (Fig. $2 \mathrm{~B}, 4 \mathrm{~B}$ ). It is noteworthy that ammonia began to accumulate again in the lower hypolimnion in late August and increased over time (Fig. 4A). The DO concentration at the time when ammonia began to reaccumulate is estimated to be $0.6-0.7 \mathrm{mg}$ $1^{-1}$ (in between $3 \%$ and $10 \%$ ) from Figure $2 \mathrm{~B}$. When DO decreased further to $3 \%(0.3 \mathrm{mg}$. $\left.\mathrm{I}^{-1}\right)$, nitrite reached a maximum of $0.26 \mu \mathrm{g}$ atom $\mathrm{N} \cdot \mathrm{l}^{-1}$ at $25 \mathrm{~m}$ on 25 September (Fig. $4 \mathrm{C}$ ). Water mass having $2 \%\left(0.2 \mathrm{mg} \cdot \mathrm{l}^{-1}\right)$ DO saturation appeared in the lower hypolimnion in the partial circulation period (Fig. 2B). This water mass almost coincided with the water mass having minimum nitrate of less than 0.2 

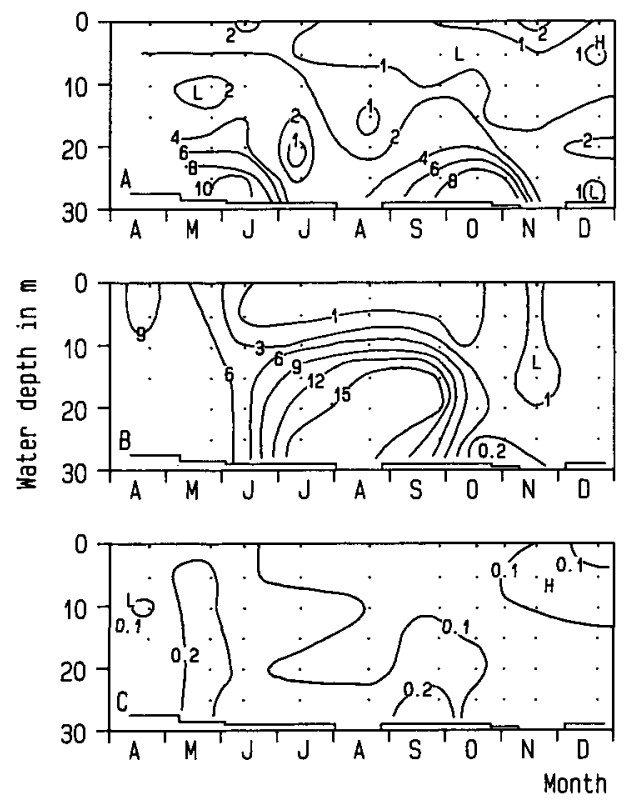

Fig. 4. Depth-time diagrams. A) ammonia; B) nitrate; C) nitrite in $\mu \mathrm{g}$ atom $\mathrm{N} \cdot 1^{-1}$.

$\mu \mathrm{g}$ atom $\mathrm{N} \cdot \mathrm{I}^{-1}$ (Fig. 4B).

These facts indicate that nitrification predominated until the DO level decreased to about $0.6-0.7 \mathrm{mg} \cdot 1^{-1}$. In Lake Kizaki, both nitrification and denitrification activities were detected in oxygen stratum as low as $0.04-0.20$ $\mathrm{mg} \cdot \mathrm{l}^{-1}$ (Yoн et al., 1990). Therefore, nitrification might proceed under conditions of $0.6-0.7$ $\mathrm{mg} \cdot \mathrm{l}^{-1}$ of DO. However, notable reaccumulation of ammonia strongly suggests that nitrification was no longer efficient below about $0.6-0.7 \mathrm{mg} \cdot 1^{-1}$ DO level. In the hypolimnion of Lake Rotoiti, a deep mesotrophic lake in New Zealand, ammonia reaccumulated linearly when DO decreased to about $0.6 \mathrm{mg} \cdot \mathrm{l}^{-1}$ (data from Fig. 1 in Downes, 1988). A DO level of about $0.6-0.7 \mathrm{mg} \cdot 1^{-1}$ seems to be critical in impeding efficient nitrification. When DO decreased to $3-2 \%(0.3-0.2 \mathrm{mg}$ $\mathrm{l}^{-1}$ ), denitrification seems to have taken place at the bottom sediment and/or in the lower hypolimnetic water. However, to prove whether or not denitrification really takes place in this lake requires further study.

Hypolimnetic gross ammonia production rate was estimated to be $0.05-0.15 \mu \mathrm{g}$ atom $\mathrm{N}$. $\mathrm{l}^{-1} \cdot \mathrm{day}^{-1}$ from spring to autumn as follows. Based on the depth-time diagrams for ammonia (Fig. 4A) and nitrate (Fig. 4B), nitrification started between 13 June and 10 July. In Lake Kizaki, pre-existing ammonia was stoichiometrically oxidized to nitrate from 15 June to 4 - 15 July, 1979 (TaKahashi et al., 1982). However, the amount of the pre-existing ammonia was insufficient to account for the nitrate production in the present study (compare column $\mathrm{A}$ in Table 2 with column I in Table 3). The difference between the preexisting ammonia and the nitrate produced must be accounted for by the production of ammonia, which might be nitrified immediately after the production. If this is the case, the gross ammonia production rate can be calculated (columns $\mathrm{P}$ and $\mathrm{Q}$ in Table 3 ) as ranging from $0.05-0.14 \mu \mathrm{g}$ atom $\mathrm{N} \cdot 1^{-1} \cdot \mathrm{day}^{-1}$ at an average of $0.11 \mu \mathrm{g}$ atom $\mathrm{N} \cdot 1^{-1} \cdot \mathrm{day}^{-1}$. The net ammonia production rate in the period from 18 August to 25 September (column $\mathrm{N}$ in Table 3) and that at $25 \mathrm{~m}$ from 25 September to 15 October (column $\mathrm{O}$ in Table 3 ) were of the same magnitude relative to the gross ammonia production rates from spring to early summer. Differences in the concentration of nitrate in these periods were slightly negative (columns $\mathrm{C}$ and $\mathrm{D}$ in Table 2), indicating that nitrification was negligible, if it occurred at all. If this is the case, the net ammonia production rate in these periods should equal the gross rate. These facts indicate that the gross ammonia production rate in the hypolimnion varied within a fairly narrow range between 0.05 and $0.15 \mu \mathrm{g}$ atom $\mathrm{N} \cdot \mathrm{l}^{-1} \cdot \mathrm{day}^{-1}$ from spring to autumn. However, the gross rate thus estimated decreased with depth in spring, whereas it increased in autumn. Though the mechanism underlying this difference is a matter of great importance, it remains to be explained. In the hypolimnion of Lake Rotoiti, New Zealand, the net rate of ammonia accumulation of $0.2 \mu \mathrm{g}$ atom $\mathrm{N} \cdot 1^{-1} \cdot \mathrm{day}^{-1}$ was observed (Downes, 1988). The present accumulation rates are slightly less than those in Lake Rotoiti. 
Table 2. Differences in concentrations of nitrate and nitrification rates at some layers in the hypolimnion during assigned period.

$\Delta \mathrm{NO}_{3}{ }^{-}\left(\mu \mathrm{g}\right.$ atom $\left.\mathrm{N} \cdot 1^{-1}\right)$

\begin{tabular}{ccccc}
\hline $\begin{array}{c}\text { Depth } \\
(\mathrm{m})\end{array}$ & $\mathrm{A}$ & $\mathrm{B}$ & $\mathrm{C}$ & $\mathrm{D}$ \\
\hline 15 & $13 \mathrm{~J}-10 \mathrm{~J}$ & $10 \mathrm{~J}-18 \mathrm{~A}$ & $18 \mathrm{~A}-25 \mathrm{~S}$ & $25 \mathrm{~S}-15 \mathrm{O}$ \\
\hline 20 & +5.65 & +5.79 & -0.87 & $(-10.83)^{*}$ \\
25 & +7.36 & +4.64 & -0.35 & $(-11.38)^{*}$ \\
& +11.82 & +2.13 & -6.71 & -10.61 \\
\hline & & Nitrification rate $\left(\mu \mathrm{g}\right.$ atom N $\cdot \mathrm{l}^{-1} \cdot$ day $\left.^{-1}\right)$ & \\
\hline Depth & $\mathrm{E}=\mathrm{A} / 27 \mathrm{~d}$ & $\mathrm{~F}=\mathrm{B} / 40 \mathrm{~d}$ & $\mathrm{G}=\mathrm{C} / 38 \mathrm{~d}$ & $\mathrm{H}=\mathrm{D} / 40 \mathrm{~d}$ \\
$(\mathrm{~m})$ & $13 \mathrm{~J}-10 \mathrm{~J}$ & $10 \mathrm{~J}-18 \mathrm{~A}$ & $18 \mathrm{~A}-25 \mathrm{~S}$ & $25 \mathrm{~S}-15 \mathrm{O}$ \\
\hline 15 & +0.21 & +0.14 & -0.023 & $(-0.25)^{*}$ \\
20 & +0.27 & +0.12 & -0.013 & $(-0.54)^{*}$ \\
25 & +0.44 & +0.053 & -0.16 & -0.53 \\
\hline
\end{tabular}

Table 3. Differences in concentration of ammonia and net/gross ammonia production rates at some layers in the hypolimnion during assigned period.

$\Delta \mathrm{NH}_{3}\left(\mu \mathrm{g}\right.$ atom $\left.\mathrm{N} \cdot 1^{-1}\right)$

\begin{tabular}{ccccc}
\hline $\begin{array}{c}\text { Depth } \\
(\mathrm{m})\end{array}$ & $\mathrm{I}$ & $\mathrm{J}$ & $\mathrm{K}$ & $\mathrm{L}$ \\
& $13 \mathrm{~J}-10 \mathrm{~J}$ & $10 \mathrm{~J}-18 \mathrm{~A}$ & $18 \mathrm{~A}-25 \mathrm{~S}$ & $25 \mathrm{~S}-15 \mathrm{O}$ \\
\hline 15 & -1.91 & -1.36 & +1.71 & $(-0.35)^{*}$ \\
20 & -4.27 & +0.62 & +2.29 & $(+0.59)^{*}$ \\
25 & -10.35 & +1.90 & +3.74 & +2.97 \\
\hline & Net ammonia production rate $\left(\mu \mathrm{g}\right.$ atom $\left.\mathrm{N} \cdot \mathbf{1}^{-1} \cdot \mathrm{day}^{-1}\right)$ & \\
\hline Depth & $\mathrm{M}=\mathrm{J} / 40 \mathrm{~d}$ & $\mathrm{~N}=\mathrm{K} / 38 \mathrm{~d}$ & $\mathrm{O}=\mathrm{L} / 40 \mathrm{~d}$ \\
$(\mathrm{~m})$ & $10 \mathrm{~J}-18 \mathrm{~A}$ & $18 \mathrm{~A}-25 \mathrm{~S}$ & $25 \mathrm{~S}-15 \mathrm{O}$ \\
\hline 15 & - & - & +0.045 & $(-)^{*}$ \\
20 & - & +0.016 & +0.060 & $(+0.030)^{*}$ \\
25 & - & +0.048 & +0.098 & +0.15 \\
\hline
\end{tabular}

Gross ammonia production rate $\left(\mu \mathrm{g}\right.$ atom $\mathrm{N} \cdot 1^{-1} \cdot$ day $^{-1}$ )

\begin{tabular}{ccccc}
\hline $\begin{array}{c}\text { Depth } \\
(\mathrm{m})\end{array}$ & $\begin{array}{c}\mathrm{P}=(\mathrm{A}+\mathrm{I}) / 27 \mathrm{~d} \\
13 \mathrm{~J}-10 \mathrm{~J}\end{array}$ & $\begin{array}{c}\mathrm{Q}=(\mathrm{B}+\mathrm{J}) / 40 \mathrm{~d} \\
10 \mathrm{~J}-18 \mathrm{~A}\end{array}$ & & \\
\hline 15 & +0.14 & +0.11 & - & $(-)^{*}$ \\
20 & +0.11 & +0.13 & - & $(-)^{*}$ \\
25 & +0.054 & +0.10 & - & - \\
\hline
\end{tabular}

* Water was circulated down to $20 \mathrm{~m}$.

The nitrification rate in the period from 13 June to 10 July ranged $0.21-0.44 \mu$ g atom $\mathrm{N}$. $1^{-1} \cdot$ day $^{-1}$ (column $\mathrm{E}$ in Table 2). It increased with depth. The concentration of pre-existing ammonia also increased with depth (Fig. 4A), indicating that the nitrification rate in this period was regulated by the concentration of the pre-existing ammonia. Active nitrification in many lakes in moderate latitudes throughout the world such as Lake Kizaki starts abruptly between June and July (TAKAHASHI, 1987). A possible mechanism to 
explain this sudden start of active nitrification was studied by Yoshioka and Sayo (1985) in terms of photoinhibition to nitrifiers. The maximum rates during this active period in the world's lakes are as great as $1.3-1.7 \mu \mathrm{g}$ atom $\mathrm{N} \cdot \mathrm{I}^{-1} \cdot \mathrm{day}^{-1}$ (TAKAHASHI, 1987). In Lake Kiza$\mathrm{ki}$, after about a month into this active period, the rate decreased to about $1 / 10$ and maintained this level untill the autumn circulation period (TAKAHASHI, 1987). In our study, the period between 13 June and 10 July seems to have been the active nitrification period. However, the maximum rate in our study is extremely small compared with that in TAKAHASHI, (1987), because our sampling was too coarse both spatially and temporally to detect the maximum nitrification rate at a specific depth on a specific day.

3-4. Transparency, Chl. a, TN, TP and trophic state

Based on the levels of transparency, Chl. a, TN and TP during the autumn circulation period, Lake Hibara is on the boundary between oligo- and mesotrophic. However, the water mass occupying the epilimnion during the summer stratification period was oligotrophic.

When the period from 25 May to 25 September is taken as the thermal stratification period (Fig. 2A), transparency during this period ranged from $3.2 \mathrm{~m}$ on 10 July to $6.5 \mathrm{~m}$ on 18 August with an average of $4.9 \mathrm{~m}$ (Table 4). Most of the transparencies in this period fall into the oligotrophic range (ForsBerg and Ryding, 1980). TP in the epilimnion during the stratification period was up to about $0.4 \mu \mathrm{g}$ atom $\mathrm{P} \cdot \mathrm{I}^{-1}$ and lower than those in the metaand hypolimnion (Fig. 5C). This epilimnetic TP falls into the oligotrophic range (FORSBERG and Ryding, 1980). TN in the epilimnion was roughly about $10 \mu \mathrm{g}$ atom $\mathrm{N} \cdot \mathrm{l}^{-1}$ (Fig. 5B). This $T N$ concentration agrees with those of oligotrophic lakes (ForsBERG and RYding, 1980). Epilimnetic Chl. a was $2-4 \mu \mathrm{g} \cdot \mathrm{I}^{-1}$ from June to August (Fig. 5A). This range falls between the boundary of oligotrophy and mesotrophy
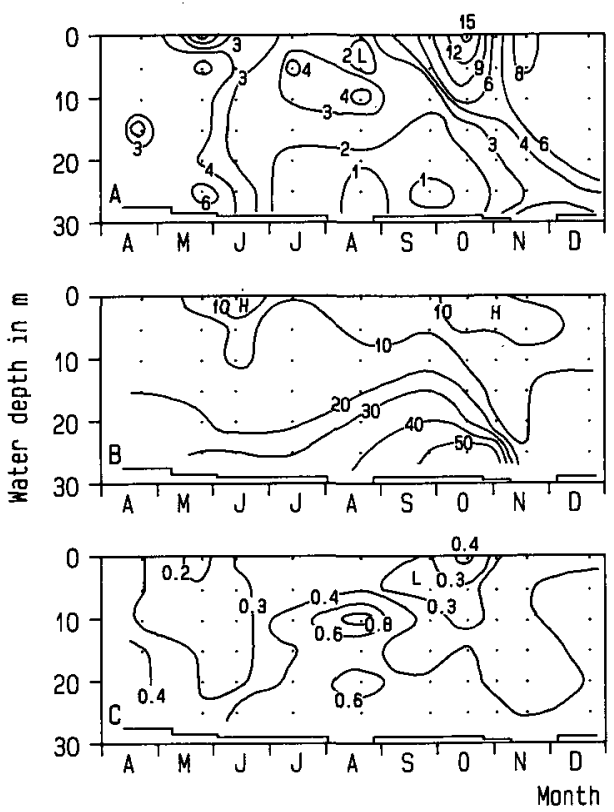

Fig. 5. Depth-time diagrams. A) Chl. $\mathrm{a}\left(\mu \mathrm{g} \cdot 1^{-1}\right)$; B) $\mathrm{TN}\left(\mu \mathrm{g}\right.$ atom $\left.\mathrm{N} \cdot \mathrm{l}^{-1}\right)$; C) $\mathrm{TP}(\mu \mathrm{g}$ atom $\left.\mathrm{P} \cdot 1^{-1}\right)$.

Table 4. Seasonal changes in transpareny in $\mathrm{m}$.

\begin{tabular}{|c|c|c|c|c|c|}
\hline \multicolumn{2}{|r|}{ Date } & \multirow{2}{*}{$\frac{\text { Transparency }}{2.6}$} & \multicolumn{2}{|c|}{ Date } & \multirow{2}{*}{$\frac{\text { Transparency }}{6.3}$} \\
\hline & Apr. & & 2 & Sept.* & \\
\hline & May & 4.7 & 25 & Sept. & 5.1 \\
\hline & June & 5.0 & 2 & Oct. ${ }^{*}$ & 2.9 \\
\hline 10 & July & 3.2 & 8 & Oct. ${ }^{*}$ & 3.4 \\
\hline & July* & 4.2 & 15 & Oct. & 3.2 \\
\hline & July* & 3.9 & 31 & Oct. & 2.9 \\
\hline 18 & Aug. & 6.5 & 15 & Nov. & 3.3 \\
\hline & Aug.* & 5.2 & 20 & Dec. & 3.6 \\
\hline
\end{tabular}

* Only depth profile of water temperature and transparency were measured. 
(Forsberg and Ryding, 1980). Thus, the epilimnetic water during the stratification period was oligotrophic.

However, the circulation period is the proper season to determine the trophic state of lakes (Sакамото, 1962). The transparency during the partial and complete circulation periods in autumn was significantly lower than that in the summer stratification period. It ranged between 2.9 and $3.6 \mathrm{~m}$, with an average of $3.2 \mathrm{~m}$ (Table 4). The transparencies in this period corresponded to those of mesotrophic lakes (ForsBerg and Ryding, 1980). The annual Chl. a maximum of $15 \mu \mathrm{g} \cdot 1^{-1}$ was recorded in the surface water at the beginning of the autumn partial circulation. The Chl. a maximum accompanied a small TP maximum (Fig. 5A, C). This Chl. a level corresponds to those of eutrophic lakes, while TP corresponds to the oligotrophic level (ForsBerg and RYding, 1980). The concentration of Chl. a subsequently decreased gradually to the mesotrophic level of $6.5 \mu \mathrm{g} \cdot \mathrm{l}^{-1}$ by 20 December (Fig. 5A). TN and $\mathrm{TP}$ remained consistently in the oligotrophic ranges during this period (Fig. 5B, C). Thus, transparency falls into the mesotrophic range, Ch1. a level falls between the mesn- and entrophic ranges, while TN and TP were within the oligotrophic ranges. Judging from these conditions, we classified Lake Hibara to be on the boundary between oligo- and mesotrophic lakes. According to KuROSAKI and Kadota (1989), the number of zooplankton species in Lake Hibara began to increase in 1965. The number of rotifer species including index species for mesotrophic or meso- to eutrophic has noticeably increased of late. They classified Lake Hibara to be mesotrophic.

A high TP water mass of $0.4-0.8 \mu \mathrm{g}$ atom $\mathrm{P} \cdot \mathrm{1}^{-1}$ lay just in the metalimnion from July to September (Fig. 5B). Some part of TP in this maximum seems to have been living phytoplankton: the TP maximum of $0.80 \mu \mathrm{g}$ atom $\mathrm{P} \cdot \mathrm{l}^{-1}$ found at $10 \mathrm{~m}$ on 18 August overlapped the Chl. a maximum of $4.5 \mu \mathrm{g} \cdot \mathrm{l}^{-1}$ (Fig. $5 \mathrm{~A}, \mathrm{C})$. Since the transparency on this day was $6.5 \mathrm{~m}$ (Table 4), Chl. a at $10 \mathrm{~m}$ might originate from living phytoplankton cells. Phytoplan- kton sometimes accumulate at the lower trophogenic zone for some reason, though why this occurs in Lake Hibara is not yet clear. The metalimnetic density difference of water sometimes acts as a physical barrier entrapping falling particles. Another possible reason is that phytoplankton congregate in this layer in order to utilize nutrients which diffuse up from the hypolimnion (e.g. Lake Kizaki in TaKaHASI, 1987).

TN increased with depth during the summer stagnation period (Fig. 5C). It reached a maximum of $59.8 \mu \mathrm{g}$ atom $\mathrm{N} \cdot 1^{-1}$ at $25 \mathrm{~m}$ on 15 October. Total inorganic nitrogen (TIN) was about $10 \mu \mathrm{g}$ atom $\mathrm{N} \cdot \mathrm{l}^{-1}$, which consisted of 9.8 $\mu \mathrm{g}$ atom $\mathrm{N} \cdot \mathrm{l}^{-1}$ of ammonia, $0.22 \mu \mathrm{g}$ atom $\mathrm{N} \cdot$ $1^{-1}$ of nitrate and $8.06 \mu \mathrm{g}$ atom $\mathrm{N} \cdot 1^{-1}$ of nitrite. About $50 \mu \mathrm{g}$ atom $\mathrm{N} \cdot 1^{-1}$, the difference between $\mathrm{TN}$ and TIN, must be organic nitrogen.

\section{$3-5$. Relative areal oxygen deficit}

The relative areal oxygen deficit is another criterion used in discussing the trophic state of a lake (WETzEL, 1983). However, the application of this method in a complicated lake basin like that of Lake Hibara is problematic, since it is difficult to determine the extent of the subbasin in which the sampling station in question exists. There is a submerged steep cliff just south of our sampling station. We assumed line $A-A^{\prime}$ in Figure 1, which is roughly the edge of the cliff, to be the southern boundary of the sub-basin of our station (Fig. 1). There is another submerged cliff about $1 \mathrm{~km}$ north of the station. The edge of this cliff is shown by the line $\mathrm{B}-\mathrm{B}$ ' and was assumed to be the northern boundary. The relative areal oxygen deficit was calculated to be $0.061 \mathrm{mg} \cdot \mathrm{cm}^{-2} \cdot$ day $^{-1}$ (Table 5). Wetzel recommended Mortimer's criteria (1941, cited in WETzEL, 1983) in which $0.025 \mathrm{mg} \cdot \mathrm{cm}^{-2} \cdot$ day $^{-1}$ indicated the upper limit of oligotrophy and $0.055 \mathrm{mg} \cdot \mathrm{cm}^{-2} \cdot$ day $^{-1}$ the lower limit of eutrophy. The relative areal oxygen deficit of our sub-basin is slightly greater than that of MorTimer's lower limit of eutrophy. To assess the reliability of that estimate, alternate boundaries of the sub-basin were selected. Lines $\mathrm{C}-\mathrm{C}^{\prime}$ and D - D' show the alternate south and north boundaries, 
Table 5. Calculation of relative areal oxygen deficits.

\begin{tabular}{cccccc}
$\begin{array}{c}\text { Strata } \\
(\mathrm{m})\end{array}$ & $\begin{array}{c}\text { Volume } \\
\left(\mathrm{km}^{3}\right)\end{array}$ & $\begin{array}{c}\text { DO }\left(\mathrm{mg} \cdot \mathrm{l}^{-1}\right) \\
25 \mathrm{May}\end{array}$ & $\begin{array}{c}\text { DO in strata }(\mathrm{t}) \\
25 \text { May }\end{array}$ & $\begin{array}{c}\text { DO }\left(\mathrm{mg} \cdot \mathrm{l}^{-1}\right) \\
25 \text { Sept. }\end{array}$ & $\begin{array}{c}\text { DO in strata (t) } \\
25 \text { Sept. }\end{array}$ \\
\hline $10-15$ & $5.52 \times 10^{-3}$ & 8.94 & 49.3 & 1.57 & 8.7 \\
$15-20$ & $4.53 \times 10^{-3}$ & 7.64 & 34.6 & 0.42 & 1.9 \\
$20-25$ & $2.72 \times 10^{-3}$ & 6.52 & 17.7 & 0.24 & 0.7 \\
$25-30$ & $0.72 \times 10^{-3}$ & 6.27 & 4.5 & 0.23 & 0.2 \\
\hline Total & & 27 & 106.1 & & 11.5 \\
\hline
\end{tabular}

Difference of total DO during 133 days from 25 May to 25 September $=106.1-11.5=94.6(t)$ Surface area of hypolimnion at $10 \mathrm{~m}=1.17 \mathrm{~km}^{2}$

Relative areal oxygen deficit $=94.6 \mathrm{t} / 1.17 \mathrm{~km}^{2} / 133$ days

$$
=0.061 \mathrm{mg} \cdot \mathrm{cm}^{-2} \cdot \mathrm{day}^{-1}
$$

respectively (Fig. 1). The former line is on the submerged plateau behind the cliff. The latter is located at the north end of the narrow part of the lake. The relative areal oxygen deficit in this alternate sub-basin was calculated to be $0.055 \mathrm{mg} \cdot \mathrm{cm}^{-2} \cdot$ day $^{-1}$ (data not shown). These facts show that the larger we assume the area of the sub-basin to be, the smaller the relative areal oxygen deficit becomes, and vice versa. Therefore we cannot arrive at a definite estimate in this case. However, the second estimate still agrees with MoRTIMER's lower limit of eutrophy. Based on the relative areal oxygen deficit, the hypolimnetic oxygen consumption of our sub-basin corresponds to that for the lower limit of eutrophic lakes. It is quite interesting that, notwithstanding the lake's overlying oligotrophic epilimnion during the summer stratification period, a eutrophic level of hypolimnetic DO consumption was observed. Further study is needed to solve this contradiction.

It should be kept in mind that the hypolimnetic DO consumption may fluctuate from year to year as was the case in the 1970 s. If this is the case, the hypolimnetic nitrogen metabolisms in some years may differ somewhat from the present results. To elucidate the extent of the fluctuation of the hypolimnetic DO consumption from year to year is an important subject for future study.

\section{Acknowledgements}

The authors wish to thank Drs. M. TAKAHASHI and T. Nakajima at the Lake Biwa Research Institute for their valuable comments on an earlier draft of this paper.

\section{摘 要}

\section{桧原湖の栄養状態と深水層における窒素代謝}

1991 年の春加ら初冬にかけて, 桧原湖の水温, 透明度, 溶存酸素, 栄養塩等を観測し, 同湖の栄 養状態の現状と過去の変遷, 及び深水層における 窒素代謝を議論した。この湖で，これ等の季節変 化が論じられるのは初めてである。

深水層で， 6 月 13 日と 7 月 10 日の間に硝化が 始まった。この期間の硝化速度は 0.21-0.44 $\mu \mathrm{g}$ atom $\mathrm{N} \cdot \mathrm{l}^{-1} \cdot \mathrm{day}^{-1}$ であった. 溶存酸素濃度が約 0.6-0.7 mg・1 $1^{-1}$ 以下になると, 硝化は効率良く進 行しないことが示唆された.アンモニアの総生産 速度が $0.05-0.15 \mu \mathrm{g}$ atom $\mathrm{N} \cdot \mathrm{I}^{-1} \cdot \mathrm{day}^{-1}$ と見積 られた。溶存酸素濃度が $0.2-0.3 \mathrm{mg} \cdot \mathrm{I}^{-1}$ に減少す ると, 湖底表面または深水層で脱窒が起こったと 考えられる。秋期循環期の TN, TP, Chl. a 及び 透明度より，この湖崸栄養から中栄養への過渡 期にあると判断された。しかし，夏期停滞期の表 水層は，貣栄養であった．深水層における，相対 的酸素消費速度は $0.055-0.061 \mathrm{mg} \cdot \mathrm{cm}^{-2} \cdot \mathrm{day}^{-1}$ と富栄養の下限の值であった。上に位置する表水 層が筫栄養なのに, 何故富栄養レベルの溶存酸素 の消費が深水層で行われるのかは，今後の課題で ある. 深水層における溶存酸素の消費速度は, こ の 20 年間に加速されたと考えられる. 今後の課題 として重要なのは, 深水層における諸過程の年変 動の幅を明らかにすることである。 


\section{References}

BENDSChNEIDER, K. and R.J. Robinson (1952): A new spectrophotometric method for the determination of nitrite in seawater. J. mar. Res., 11: 87 $-96$.

DownEs, M.T. (1988): Aquatic nitrogen transformations at low oxygen concentrations. Appl. Envi. ron. Microbiol. 54: 172-175.

ForsBERG, C. and S-O. RYDING (1980): Eutrophication parameters and trophic state indices in 30 Swedish waste-receiving lakes. Arch. Hydrobiol., 89: 189-207.

HoRIE, S. (1961): Morphometric features and the classification of all the lakes in Japan. Mem. Coll. Sci. Univ. Kyoto (B), 28: 53-71.

KrTAGAWA, N. (1974): Studies on the bottom fauna of seven lakes of North Japan (in Japanese). Jpn. J. Limnol., 35: 162-172.

Kokubo, S. and T. Kawamura (1941): Plankton and water chemistry of Lake Akimoto and Lake Hibara (in Japanese). Seitaigaku Kenkyu, 7: 189-195.

KuRosaki, T. and S. KadoTa (1989): Limnology of Lake Hibara, Fukushima. I. Origin of lake and plankton (in Japanese). Abstract for the annual conference of Japanese Society of Limnology in 1985, Tokyo., 103.

Mentzel, D.W. and N. CoRwin (1965): The measurement of total phosphorus in seawater based on the liberation of organically bound fraction by persulfate oxidation. Limnol. Oceanogr., 10: 280-282.

Murayama, I. (1973): Volcanic Activity and Topography (in Japanese). Taimeido Publishing.

OTSUKI, A. (1981): Use of ultraviolet spectro. photometric determination of nitrate for the determination of total nitrogen in environmen. tal water samples using alkaline persulfate digestion (in Japanese). Bunseki Kagaku, 30 : 688-689.

SAKAmoto, M. (1962): Primary production and trophic degree of lakes (in Japanese)., Jpn J. Limnol. 23: 73-85.

SCOR/UNESCO (1966): Determination of Photosynthetic Pigments in Seawater. UNESCO Publication Center, New York.

SOLORZANO. L. (1969): Determination of ammonium in natural waters by the phenolhypochlorite method. Limnol. Oceanogr., 14: 799-801.

Strickland, J.D.H. and T.R. PARSONS (1972): $A$
Practical Handbook of Seawater Analysis (2nd ed.). Bull. Fish. Res. Bd. Canada 167: 1-310.

TAKaHASHI, M. (1987): Nitrogen Metabolism in the Oxygenated Zone in Lake Kizaki (in Japanese). Doctoral dissertation presented to Nagoya University.

Takahashi, M., T. Yoshioka and Y. Saijo (1982): Nitrogen metabolism in Lake Kizaki, Japan. III. Active nitrification in early summer. Arch. Hydrobiol., 93: 272-286.

TANAKA, A. (1903): Lakes in the vicinity of Volcano Bandai (in Japanese). Chigaku Zasshi, 176: 631 -636 .

Watanabe, T., K. Mashiko and H. Kamijo (1973): Water chemistry and plankton of Lake Hibara, Lake Onogawa, Lake Akimoto, and Lake Sohara on Bandai Plateau (in Japanese). Basic Studies on the Eutrophication of Inland Waters No 2., 26-28.

WeTzEL, R. (1983): Limnology (2nd ed.). Saunders College Publishing.

Yoh, M., A. YAGI and H. Teral (1990): Significance of low-oxygen zone for nitrogen cycling in a freshwater lake: Production of $\mathrm{N}_{2} \mathrm{O}$ by simultaneous denitrification and nitrification., Jpn. J. Limnol. 51: 163-171.

YoshimuRA, S. (1935a): Preliminary study on the local limnology of volcanic lakes around Volcano Bandai (1) (in Japanese). Chirigaku Hyoron, 8: 782-802.

YoshimuRA, S. (1935b): Preliminary study on the local limnology of volcanic lakes around Volcano Bandai (2) (in Japanese). Chirigaku Hyoron, 8: 860-880.

YosHIMURA, S. (1935c): Preliminary study on the local limnology of volcanic lakes around Volcano Bandai (3) (in - Japanese). Chirigaku Hyoron, 8: 933-976.

YoshoKa, T. and Y. SaIJo (1985): Active nitrification in the hypolimnion of Lake Kizaki in early summer. 2. Effects of light on nitrification in water., Arch. Hydrobiol. 105: 1-9.

（著者：佐藤泰哲 - 小出直樹 - 大㷊茂・鈴木和泉 - 鉿 木利孝, 山形大学理学部, ₹ 990 山形市小白川町 1 4 -12; Yasuhiro SAToH, Naoki KoIDE, Shigeru OASA, Izumi Suzuki, Toshitaka Suzuki, Faculty of Science, Yamagata University, Yamagata 990)

Received: 6 July 1992

Accepted: 21 September 1992 